\title{
The extracellular signal-regulated kinase $1 / 2$ pathway in neurological diseases: A potential therapeutic target (Review)
}

\author{
JING SUN and GUANGXIAN NAN
}

\author{
Department of Neurology, China-Japan Union Hospital of Jilin University, Changchun, Jilin 130000, P.R. China
}

Received May 5, 2016; Accepted April 12, 2017

DOI: $10.3892 /$ ijmm.2017.2962

\begin{abstract}
Signaling pathways are critical modulators of a variety of physiological and pathological processes, and the abnormal activation of some signaling pathways can contribute to disease progression in various conditions. As a result, signaling pathways have emerged as an important tool through which the occurrence and development of diseases can be studied, which may then lead to the development of novel drugs. Accumulating evidence supports a key role for extracellular signal-regulated kinase $1 / 2$ (ERK1/2) signaling in the embryonic development of the central nervous system (CNS) and in the regulation of adult brain function. ERK1/2, one of the most well characterized members of the mitogen-activated protein kinase family, regulates a range of processes, from metabolism, motility and inflammation, to cell death and survival. In the nervous system, ERK1/2 regulates synaptic plasticity, brain development and repair as well as memory formation. ERK1/2 is also a potent effector of neuronal death and neuroinflammation in many CNS diseases. This review summarizes recent findings in neurobiological ERK1/2 research, with a special emphasis on findings that clarify our understanding of the processes that regulate the plethora of isoform-specific ERK functions under physiological and pathological conditions. Finally, we suggest some potential therapeutic strategies associated with agents acting on the ERK1/2 signaling to prevent or treat neurological diseases.
\end{abstract}

\section{Contents}

1. Introduction

2. ERK $1 / 2$ pathway

3. ERK1/2 as effectors of physiological brain functions

4. ERK1/2 as effectors of stroke neurodegeneration and drug addiction

Correspondence to: Dr Guangxian Nan, Department of Neurology, China-Japan Union Hospital of Jilin University, 126 Xiantai Street, Changchun, Jilin 130000, P.R. China

E-mail:ngx0415@hotmail.com

Key words: extracellular signal-regulated kinase 1/2 signaling, brain, stroke, neurodegeneration, drug addiction
5. Therapeutic inhibitors of the ERK1/2 signaling cascade

6. Conclusion and perspectives

\section{Introduction}

Over the past several years, intracellular signaling targets have been intensely studied as a measure of the cellular processes that occur following specific conditions. Extracellular signal-regulated kinase 1/2 (ERK1/2) ligands interact with their receptor and/or corrector in the cell and subsequently activate the intracellular ERK1/2 signaling pathway. In vertebrates, ERK1/2 signaling begins during development and acts to regulate cell proliferation, differentiation and fate decisions in the mature individual. Dysfunction of ERK1/2 signaling is associated with several human diseases, such as cancer, asthma, stroke and Alzheimer's disease (AD) (1-4). Due to the importance of ERK1/2 in a wide range of biological processes in central nervous system (CNS) disease, better understanding of the precise mechanisms of ERK1/2 signaling may provide fundamental insight into its role in disease development as well as help identify novel targets for therapeutic applications.

\section{ERK1/2 pathway}

ERK1/2, like other protein kinases, contains unique $\mathrm{N}$ - and C-terminal extensions that provide signaling specificity. Human ERK1 consist of 378 amino acid residues while ERK2 consists of 360 amino acid residues. ERK1 and 2 differ from one anther among various species. Gene ablation studies have provided evidence that ERK1 and 2 are not entirely functionally identical. A study showed that the erk1 gene is dispensable for the development of mice, whereas ablation of the erk2 gene is embryonic lethal (5). However, ERK1 was found to play an essential role in thymocyte development in a ERK1-knockout (KO) mouse study (6). Whether functions exist that are unique or preferred to ERK1 or 2 is unknown. Maybe at one time or another during the development of an animal, ERK1 or 2 performs functions unique to that isoform. Even so, ERK1 and 2 have a high degree of similarity, with $>95 \%$ amino acid identity among humans, mice and rats (7). These two kinases share many physiological and biological functions and are commonly referred to together as ERK1/2. All known cellular stimulants of the ERK1/2 pathway lead to parallel activation of ERK1 and 2 (8). The ERK1/2 
activation ratio in cells corresponds with their expression ratio, indicating that the isoforms are activated in parallel (9).

ERK1/2 cascade. A wide variety of extracellular stimuli are capable of activating the ERK1/2 cascade. Mitogen-activated protein kinase/extracellular signal-regulated kinase (MEK)1 and 2 are the immediate upstream kinases that phosphorylate and activate ERK1/2. MEK1 and 2 are dual-specificity protein kinases that mediate the phosphorylation of tyrosine and threonine residues. The activity of MEK1/2 is also regulated by phosphorylation, as MEK1 and 2 are phosphorylated by mitogen-activated protein kinase kinase kinases (MAP3Ks). The most extensively studied MAP3Ks are the Raf proteins, including A-Raf, B-Raf,C-Raf and Raf-1 (10). They are activated by MAP4K proteins, such as Rap1, Ras, PKA and Rho (Fig. 1). ERK1/2 is a ubiquitously expressed hydrophilic non-receptor protein that participates in the Ras-Raf-MEK-ERK signal transduction cascade, which is involved in various diseases, including cancer, cardiac hypertrophy, pain and neuroinflammation (11-14). Therefore, this cascade is an interesting target for basic and translational research, including the development of drugs for therapeutic purposes.

ERK1/2 substrates. Once activated, p-ERK1/2 can translocate into the nucleus to activate a wide array of transcription factors or can simply remain in the cytoplasm, where it regulates other subcellular functions (Fig. 1). ERK1 and 2 have more than 175 documented cytoplasmic and nuclear substrates (15). ERK1/2 nuclear targets include the ternary complex factor family of transcription factors. These proteins mediate the expression of immediate early genes, whose products contribute to cell survival, division and motility $(16,17)$. Elk1 is one of the most thoroughly studied targets of the ERK1/2 MAPK kinase cascade, and Elk1 activation leads to increased transcriptional activity (15). Members of the ERK1/2 family of protein kinases participate in a wide variety of cellular processes. To date, more than 50 cytoplasmic substrates have been identified, including the ribosomal S6 kinase (RSK) family of protein kinases, apoptotic proteins and cytoskeletal proteins. The RSK family consists of four human RSK isoforms (RSK1-4), mitogen- and stressactivated kinase (MSK)1 and 2, which are directly activated by ERK1/2 in response to stimuli. RSK1-4 are key components downstream of the Raf-MEK-ERK signaling cascade. The RSK family regulates transcription by mediating the phosphorylation of various types of transcription factors, including nuclear factor- $\kappa \mathrm{B}(\mathrm{NF}-\kappa \mathrm{B})$, serum response factor (SRF) and transcription initiation factor (TIF), in cells (18).

ERK1/2 scaffolds. Scaffolds are proteins that bind to multiple components of signaling modules. Scaffolds regulate and integrate overall signal transduction and play a pivotal role in the spatial and temporal regulation of the ERK1/2 signaling cascade. In response to stimulus exposure, ERK1/2 binds to a variety of cytoplasmic scaffold and anchor proteins, including the suppressor of Ras (KSR1/2), MEK partner 1 (MP1), IQ motifcontaining GTPase activating protein 1 (IQGAP1) and MAP/ ERK kinase kinase 1 (MEKK1) (19,20). MP1, which is also known as MAP kinase scaffold protein 1 and LAMTOR3, was identified as a scaffold protein that potentiates MAPK signaling by binding to MEK1 and ERK1. MP1 is localized to endomem- brane compartments as part of larger signaling complexes and modulates the Raf-MKK1/2-ERK1/2 pathway together with its partner, p14 (21,22). In fact, IQGAP1 is a well-known regulator of signaling events involved in the MAPK pathway. The interaction between IQGAP1 and ERK1/2 plays a critical role in tumor formation, as competition for ERK1/2 binding between IQGAP1 and a peptide that encompasses the WW domain inhibits Ras and Raf-driven tumorigenesis (23). MEKK1, a MAP3 kinase, catalyzes the phosphorylation of MEK1 and 2, which are components of the ERK pathway. Xu et al (24) and Karandikar et al (25) both showed that MEKK1 binds to C-Raf, MEK1 and ERK2 of the ERK1/2 MAPK signaling module. Recent studies have suggested that KSR1 and 2 possess catalytic activity and that KSR2 participates in the assembly of a MEK1/ KSR2/B-Raf ternary complex that is responsible for promoting rabbit MEK1 phosphorylation by mouse B-Raf $(26,27)$.

\section{ERK1/2 as effectors of physiological brain functions}

ERK1/2 is abundant in the adult brain, and its activation can play multiple roles in the activity-dependent regulation of neuronal function. Mounting evidence indicates that ERK1/2 signaling plays an essential role in the development of the CNS (28). ERK1 and 2 are also involved in neuroinflammation, neural death, learning and memory formation and the regulation of synaptic plasticity in the adult nervous system.

Synaptic plasticity. Synaptic plasticity is thought to be crucial for information processing in the brain and to underlie many complex behaviours. The best studied forms of synaptic plasticity in the CNS are long-term potentiation (LTP) and long-term depression (LTD). The regulation of protein phosphorylation has an important role in the process of LTP and LTD.

Several recent studies have implicated the ERK1/2 pathway in the control of synaptic plasticity in the adult nervous system (29,30). English and Sweatt (31) investigated the role of MAPKs in regulating synaptic plasticity in adult rat neurons, with a particular focus on the modulatory role of ERK1/2 in hippocampal LTP. They provided the first demonstration of $N$-methyl-D-aspartate (NMDA)-receptor dependent activation of ERK2 in rat hippocampal area CA1 in response to LTP-inducing high-frequency stimulation and suggested a crucial regulatory role of ERK2 in synaptic plasticity. Kanterewicz et al (32) further confirmed the role of ERK1/2 in NMDA receptor-independent LTP in the hippocampus. Over the past few years, a number of studies have demonstrated that ERK1/2 activity is required for several forms of synaptic plasticity in the amygdala which is associated with fear-dependent learning (33,34). Ratto and Pizzorusso (35) offered evidence, both in vivo and in vitro, that ERK1/2 plays a crucial role in controlling synaptic plasticity in the visual cortex. Inhibition of ERK1/2 can prevent the induction of various forms of LTP and LTD in the hippocampus and amygdala $(33,36)$. These studies indicated that a requirement for ERK1/2 activation is common to many forms of synaptic plasticity but that the precise targets of ERK1/2 may differ between different types of plasticity.

Brain and development. Evidence has shown that total ERK1/2 activity controls the proliferation of certain late-born progenitor 


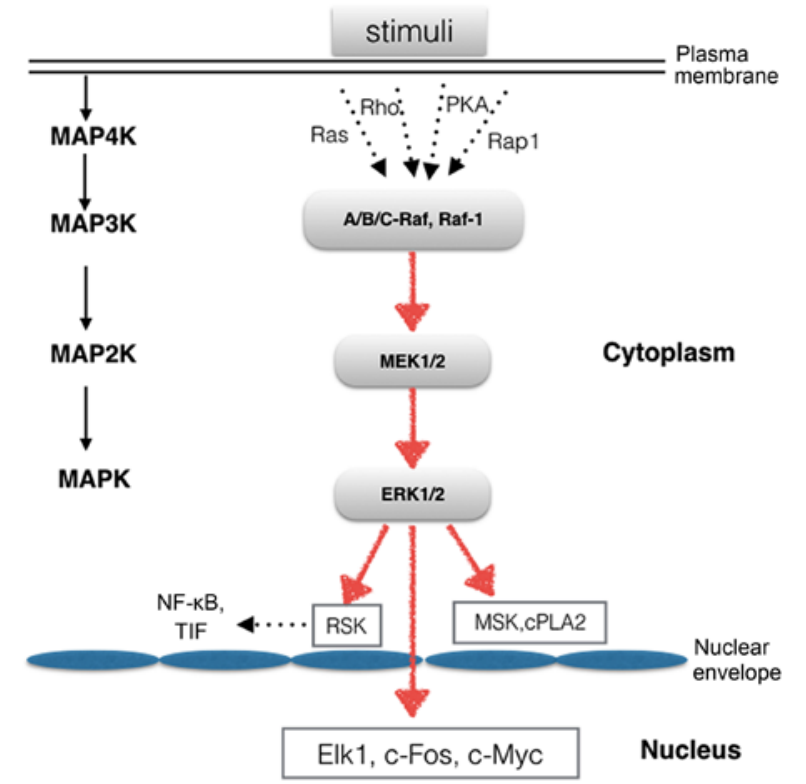

Figure 1. Extracellular signal-regulated kinase 1/2 (ERK1/2) mitogen-activated protein (MAP) kinase cascade. The ERK1/2 MAP kinase, which occur in the cytoplasm and can be translated into the nucleus, catalyze the phosphorylation of many cytosolic proteins and nuclear transcription factors.

cells and the differentiation of neurons and glia during fetal brain development and that the two may compensate for each other during this process, at least in part, due to their overlapping functions $(37,38)$. Samuels et al $(39,40)$ also found that mutations that increase ERK $1 / 2$ activity can result in macrocephaly, while mutations that decrease ERK1/2 activity can result in microcephaly, suggesting that the ERK $1 / 2$ pathway is involved in the expansion of human neural progenitor cells. Furthermore, evidence indicates that ERK1/2 also takes part in regulating the proliferation and differentiation of astrocytes in the developing brain. Li et al (41) found that MEK/ERK signaling regulated the generation of glia from radial progenitors in the developing cortex, leading to a major increase in the number of astrocytes in the brain. This finding provides insight into the mechanisms involved in ERK1/2-mediated regulation of normal and abnormal astrocyte function during brain development. Recent evidence has consistently demonstrated that the ERK1/2 pathway is one of the dominant intracellular pathways for the regulation of oligodendroglial development, myelination and remyelination $(38,42-44)$.

Neuronal cell death. Although ERK1/2 activation has generally been associated with brain cell differentiation and proliferation, a number of studies have shown that the activation of ERK1/2 can mediate cell death in several neuronal systems $(45,46)$. The different effects of ERK1/2 on brain cells may be owing to the various stimuli and cell types involved. The activation of ERK1/2 was observed in glutamate- and heme-induced neuronal cell death and the neuronal injury $(47,48)$ and loss of function $(49,50)$ were reduced when suppressing ERK1/2 activation. ERK1/2 was found to play a caspase-independent role in promoting neuronal cell death in several other models. Okadaic acid has been shown to induce pyramidal cell death in hippocampal area CA3 in a manner dependent on ERK1/2 activation but not consistent with apoptosis (51). These findings may help us design strategies that can specifically attenuate ERK1/2-promoted neuronal pathologies.

Neuroinflammation. ERK1/2 is expressed in microglia, astrocytes and oligodendrocytes. Microglial cells are the primary immune cells in the CNS and promote host defense by destroying invading pathogens (52). Intra-glial signaling, including ERK1/2 pathway cascades, controls the regulation of inflammatory cytokine production and iNOS expression in activated microglia. Many in vitro experiments have demonstrated that the ERK1/2 signaling pathway contributes to the inflammatory response in microglia that is induced upon stimulation with radiation, thrombin or LPS (53-55). ERK1/2 is also involved in the inflammatory response in astrocytes $(56,57)$. Furthermore, accumulating evidence indicates that many of the pharmaceutical-based therapies used to reduce neuroinflammation in stroke, neurodegenerative disorders, intracranial infections and other diseases act by suppressing the ERK1/2 pathway (58-61).

Learning and memory. ERK1/2 is localized in the soma and dendritic trees of neurons in the neocortex, hippocampus, striatum and cerebellum (62). An increase in ERK1/2 activation, as measured as the ratio of phosphorylated to total (phosphorylated and non-phosphorylated) ERK1/2, is necessary for learning and the formation of memory as well as for affect and arousal. In a seminal paper, Atkins et al (63) were the first to show that ERK1/2 is involved in memory processing in rat after fear conditioning. Later studies showed that activation of the ERK1/2 pathway is also required for the development of short-term memory and long-term memory consolidation $(64,65)$. Treatment with ERK1/2 inhibition can impair long-term memory retention and prevents the formation of lasting memories of an event or association, including object recognition memory $(66,67)$. Spatial learning and fear conditioning are the types of long-term memory in which the involvement of ERK1/2 has been best characterized (68). Studies of ERK1/2 KO mice demonstrated that ERK1/2 is involved in various aspects of learning and memory formation (69). ERK1 KO mice at first appear to be neurologically normal, whereas ERK2 KO is embryonic lethal; ERK2 KO mice die at embryonic day $6.5(5,70,71)$. Selcher et al (70) showed that the ERK1 isoform is not required for associative learning in mice; instead, they found that the ERK2 isoform plays a predominant role in the synaptic plasticity that underlies learning and memory. Short-term memory is retained in ERK1-KO mice, but a marked enhancement of long-term memory was found in a one-trial inhibitory avoidance task (72). The results of a re-consolidation study also support the pivotal role of ERK2 in memory process (73). These results suggest that ERK1/2 may be a target for therapeutics to treat disorders of learning and memory.

\section{ERK1/2 as effectors of stroke, neurodegeneration and drug addiction}

Consistent with its critical role in key cellular activities, including cell proliferation, differentiation, survival and death, the ERK1/2 signaling pathway has been implicated in the 
Table I. Brief overview of recent studies concerning the involvement of the ERK1/2 pathway in neurological disease.

\begin{tabular}{|c|c|c|c|c|c|}
\hline Disease & Model & Effect & Inhibitor & Outcome & References \\
\hline Stroke & MCAO model & $\begin{array}{l}\text { Regulates the expression } \\
\text { of TNF- } \beta, \text { IL- } 1 \beta \text {, } \\
\text { IL-6 and iNOS }\end{array}$ & U0126 & $\begin{array}{l}\text { Reduces infarct size and } \\
\text { improves neurological scores }\end{array}$ & $(82)$ \\
\hline Stroke & MCAO model & $\begin{array}{l}\text { Regulates the expression } \\
\text { of MMP-9 and TIMP-1 } \\
\text { in the vessel }\end{array}$ & U0126 & $\begin{array}{l}\text { Reduces infarct volume and } \\
\text { improves neurological function }\end{array}$ & $(109)$ \\
\hline Stroke & $\begin{array}{l}\text { MCAO; organ } \\
\text { culture of } \\
\text { cerebral arteries }\end{array}$ & $\begin{array}{l}\text { Regulates the expression } \\
\text { of vascular endothelin } \\
\text { type B receptor }\end{array}$ & U0126 & $\begin{array}{l}\text { Attenuates cerebral } \\
\text { vasoconstriction and } \\
\text { improves long-term } \\
\text { neurologic outcome }\end{array}$ & $(110)$ \\
\hline Stroke & $\begin{array}{l}\text { MCAO model; } \\
\text { organ culture of } \\
\text { isolated cerebral } \\
\text { arteries }\end{array}$ & $\begin{array}{l}\text { Regulates the level of } \\
\text { IL-1 } \beta, \text { TNF- } \alpha, \text { iNOS, } \\
\text { IL-6, cxcl2, MMP9 } \\
\text { and MMP13 }\end{array}$ & U0126 & $\begin{array}{l}\text { Attenuates the expression of } \\
\text { inflammatory and extracellular } \\
\text { matrix-related genes in the } \\
\text { smooth muscle cells of } \\
\text { cerebral arteries }\end{array}$ & $(111)$ \\
\hline Stroke & $\begin{array}{l}\text { MCAO model; } \\
\text { organ culture of } \\
\text { isolated cerebral } \\
\text { arteries }\end{array}$ & $\begin{array}{l}\text { Regulates the expression } \\
\text { of TNF- } \alpha \text { and TNF- } \alpha \\
\text { receptor } 1 \text { and } 2\end{array}$ & U0126 & $\begin{array}{l}\text { Reduces the expression of } \\
\text { TNF- } \alpha \text {, TNF-R } 1 \text { and TNF-R } 2 \\
\text { in the wall of cerebral arteries }\end{array}$ & $(112)$ \\
\hline Stroke & $\begin{array}{l}\text { Thrombin } \\
\text { injection-induced } \\
\text { brain injury }\end{array}$ & $\begin{array}{l}\text { Involved in thrombin-induced } \\
\text { striatal neuronal death }\end{array}$ & PD98059 & $\begin{array}{l}\text { Reduces the size of the } \\
\text { injured area }\end{array}$ & $(79)$ \\
\hline Stroke & ICH model & $\begin{array}{l}\text { Involved in ICH-induced } \\
\text { neuronal injury }\end{array}$ & PD98059 & Blocks striatal tissue injury & $(81)$ \\
\hline Stroke & $\begin{array}{l}\text { Cultured human } \\
\text { cerebral arteries }\end{array}$ & $\begin{array}{l}\text { Regulates the expression of } \\
\text { vascular contractile receptors }\end{array}$ & $\begin{array}{l}\text { SB386023; } \\
\text { SB590885 }\end{array}$ & Decreases vasoconstriction & (76) \\
\hline Stroke & SAH model & $\begin{array}{l}\text { Regulates cerebrocascular } \\
\text { inflammatory mediators } \\
\text { IL-1 } \beta, \text { IL-6, iNOS, } \\
\text { MMP-9 and TIMP-1 }\end{array}$ & SB386023-b & $\begin{array}{l}\text { Prevents the reduction in } \\
\text { cerebral blood flow }\end{array}$ & $(80)$ \\
\hline Stroke & SAH model & $\begin{array}{l}\text { Regulates cerebrovascular } \\
\text { expression of } \\
\text { pro-inflammatory } \\
\text { mediators IL-1 } 1 \beta \text {, IL- } 6 \text {, } \\
\text { TNF- } \alpha \text { and MMP-9 }\end{array}$ & U0126 & $\begin{array}{l}\text { Improves neurological } \\
\text { function }\end{array}$ & $(83)$ \\
\hline Stroke & SAH model & $\begin{array}{l}\text { Regulates the expression } \\
\text { of cerebrovascular smooth } \\
\text { muscle cell receptors }\end{array}$ & SB386023-b & $\begin{array}{l}\text { Prevents reductions in regional } \\
\text { cerebral blood flow and } \\
\text { neurological scores }\end{array}$ & $(84)$ \\
\hline Stroke & SAH model & $\begin{array}{l}\text { Regulates the phosphorylation } \\
\text { of ERK } 1 / 2 \text { and NF- } \kappa B \\
\text { activation as well as } \\
\text { the level of IL- } 1 \beta \text {, IL- } 6 \text {, } \\
\text { COX- } 2 \text {, MMP-9 }\end{array}$ & BAY 43-9006 & $\begin{array}{l}\text { Reduces vasospasm, } \\
\text { cerebral edema and } \\
\text { blood brain barrier permeability }\end{array}$ & $(113)$ \\
\hline Stroke & SAH model & $\begin{array}{l}\text { Regulates endothelium B and } \\
\text { 5-hydroxytryptamine 1B } \\
\text { receptors }\end{array}$ & SB386023-b & $\begin{array}{l}\text { Prevents cerebral blood } \\
\text { flow reduction }\end{array}$ & $(114)$ \\
\hline PD & $\begin{array}{l}\text { PC12 cells } \\
\text { culture }\end{array}$ & $\begin{array}{l}\text { Regulates ERK } 1 / 2 \\
\text { phosphorylation and } \\
\text { apoptosis in PC } 12 \text { cells }\end{array}$ & $\begin{array}{l}\text { GW5074; } \\
\text { U0126 }\end{array}$ & $\begin{array}{l}\text { Ameliorates cell } \\
\text { toxicity induced by } \\
\text { 6-hydroxydopamine }\end{array}$ & $(115)$ \\
\hline $\mathrm{AD}$ & AD model & $\begin{array}{l}\text { Regulates the time } \\
\text { exploring a novel object }\end{array}$ & PD98059 & Reverses memory impairment & $(78)$ \\
\hline $\mathrm{AD}$ & $\begin{array}{l}\text { Culture of } \\
\text { lymphoblasts } \\
\text { from AD patients }\end{array}$ & $\begin{array}{l}\text { Control cell survival or } \\
\text { death decision under } \\
\text { trophic factor withdrawal }\end{array}$ & PD98059 & $\begin{array}{l}\text { Prevents cell death induced } \\
\text { by serum starvation }\end{array}$ & (116) \\
\hline
\end{tabular}


Table I. Continued.

\begin{tabular}{|c|c|c|c|c|c|}
\hline Disease & Model & Effect & Inhibitor & Outcome & References \\
\hline $\mathrm{AD}$ & $\begin{array}{l}\text { Metabolically } \\
\text { competent rat } \\
\text { brain slice }\end{array}$ & $\begin{array}{l}\text { Regulates the phosphorylation of } \\
\text { tau at Ser198/Ser199/Ser202, } \\
\text { Ser262/Ser356 and Ser422 }\end{array}$ & U0126 & $\begin{array}{l}\text { A lesser extend of tau } \\
\text { hyperphophorylation in } \\
\text { OA-treated rat brain slice }\end{array}$ & (117) \\
\hline $\mathrm{AD}$ & $\begin{array}{l}\text { Hippocampal } \\
\text { slice culture }\end{array}$ & $\begin{array}{l}\text { Regulates the activation of } \\
\text { caspase- } 3 \text { and tau cleavage }\end{array}$ & U0126 & $\begin{array}{l}\text { Attenuates the neurotoxic } \\
\text { effects of soluble } A \beta \text { oligomer } \\
\text { in the hippocampus }\end{array}$ & (118) \\
\hline $\mathrm{AD}$ & $\begin{array}{l}\text { Rat brain } \\
\text { synaptosome } \\
\text { fraction }\end{array}$ & $\begin{array}{l}\text { Regulates the activation } \\
\text { of cPLA } 2 \text { and arachidomic } \\
\text { acid release }\end{array}$ & U0126 & $\begin{array}{l}\text { Reduces the amyloid beta peptide } \\
\text { fragment beta } A(25-35) \text {-induced } \\
\text { formation of reactive oxygen species }\end{array}$ & (119) \\
\hline $\begin{array}{l}\text { Drug } \\
\text { addiction }\end{array}$ & $\begin{array}{l}\text { Cocaine- } \\
\text { treated rat }\end{array}$ & $\begin{array}{l}\text { Mediates cocaine-induced } \\
\text { reduction of GABAergic } \\
\text { inhibition and facility of } \\
\text { LTP induction }\end{array}$ & $\begin{array}{l}\text { U0126; } \\
\text { SL327 }\end{array}$ & $\begin{array}{l}\text { Reduces the level of D2 receptor (U0126) } \\
\text { and blocks cocaine-induced faciliation } \\
\text { of LTP induction (SL327) and } \\
\text { I-LTD (U0126 and SL327) }\end{array}$ & (120) \\
\hline $\begin{array}{l}\text { Drug } \\
\text { addiction }\end{array}$ & $\begin{array}{l}\text { Ethanol- } \\
\text { treated mice }\end{array}$ & $\begin{array}{l}\text { Regulates binge-like } \\
\text { alcohol consumption }\end{array}$ & SL327 & $\begin{array}{l}\text { Increases ethanol bing-like consumption } \\
\text { and home-cage alcohol consumption }\end{array}$ & (97) \\
\hline ALS & $\begin{array}{l}\text { Microglia } \\
\text { culture }\end{array}$ & $\begin{array}{l}\text { Regulates AP- } 1 \text { activity, } \\
\text { COX- } 2 \text { expression and } \\
\text { PGE } 2 \text { production }\end{array}$ & U0126 & $\begin{array}{l}\text { Inhibition of COX- } 2 \text { expression } \\
\text { and PGE } 2 \text { production by celecoxib } \\
\text { reduces the neurotoxicity triggered } \\
\text { by TDP-43-deficient microglia }\end{array}$ & (61) \\
\hline
\end{tabular}

ERK1/2, extracellular signal-regulated kinase 1/2; AD, Alzheimer's disease; PD, Parkinson's disease; IL, interleukin; TNF, tumor necrosis factor; ALS, amyotrophic lateral sclerosis; MCAO model, middle cerebral artery occlusion model; ICH model, intracerebral hemorrhage; SAH model, subarachnoid hemorrhage.

pathogenesis of many CNS diseases, including stroke, $\mathrm{AD}$, and Parkinson's disease (PD), among others (74-78). The activation of ERK1/2 cascades contributes to disease progression through the regulation of neuronal apoptosis, neuroinflammation and synaptic plasticity.

Stroke. ERK1/2 pathway activation is also known to play physiological and pathological roles post-development, and a large body of evidence suggests that ERK1/2 also contributes to the regulation of inflammatory responses, cytokines, cell apoptosis and death in ischemic and hemorrhagic brain injury (78-82). Several pharmacological studies have also demonstrated that suppression of ERK1/2 activation frequently downregulates features of apoptosis and inflammation and reduces neurological damage after stroke (49,81-83). Madami and Edvinsson showed that the elevated microvascular pro-inflammatory cytokine expression observed following focal ischemia in MCAO models also involved the ERK1/2 pathway (82). Moreover, Shioda et al (3) found that ERK1/2 signaling plays an important role in neurogenesis following brain ischemia. Substantial evidence has suggested that the ERK1/2 pathway is involved in regulating the changes in inflammation, cytotoxicity and cerebral vasospasm that occur after hemorrhagic stroke $(76,84)$. Recently, Feng et al (85) showed that Ras/Raf/ERK signals participate in the neuronal apoptosis observed in the hippocampus in early post-subarachnoid hemorrhage brain injury. Taken together, these results suggest that therapies targeted at suppression of the ERK1/2 pathway may be beneficial in stroke.
$P D$. PD is the second most prevalent neurodegenerative disease after $\mathrm{AD}$ and is characterized by selective dopaminergic neuronal loss in the substantial nigra. The ERK1/2 pathway is known to play a major regulatory role in PD-related cellular processes. Accumulating evidence indicates that microglial cells play a crucial role in the degeneration of dopaminergic neurons in animal models of PD. Recent studies have shown that the oxidative stress response plays a central role in the etiology of PD $(86,87)$. The oxidative stress response that occurs in microglia is mediated by the activation of the ERK1/2 signaling pathway upon stimulation with pro-inflammatory stimuli. Furthermore, ERK1/2 has been shown to participate in L-DOPA-induced dyskinesia through striatal synaptic plasticity $(75,88)$. In addition, in the dopamine-depleted striatum, ERK1/2 plays an important role in the development of L-DOPA-induced dyskinesia in both mouse and non-human primate models of PD $(75,89)$. The inhibition of ERK1/2 attenuated LID and completely inhibited all markers of angiogenesis in rat and mouse models of $\operatorname{LID}(75,90)$. Therefore, the modulation of ERK1/2 in response to dopamine in PD patients may be therapeutic for motor complications.

$A D . \mathrm{AD}$ is a neurodegenerative disease that is characterized by progressive cognitive decline and memory dysfunction as well as the presence of neurofibrillary tangles (NFTs) and senile plaques composed primarily of $\beta$-amyloid. ERK $1 / 2$ is one of the kinases known to phosphorylate tau and has been shown to be associated with NFTs and senile plaques (74). Increased levels of activated ERK1/2 have been found in AD 
brains, and inhibition of the pathway can reduce $\beta$-amyloid neurotoxicity (91-93). Activated ERK1/2 is found specifically in intracytoplasmic punctate structures and intracellular NFTs, primarily in the subpopulation of neurons that exhibits early AD-related protein deposition. As mentioned above, ERK1/2 is known to play a critical role in hippocampus synaptic plasticity and learning and memory. Abnormal ERK1/2 activation in the hippocampus may impair hippocampal function and contribute to memory deficits in AD patients. Therefore, improving regulation of the ERK1/2 pathway may be a central facet for the development of potential treatments for $\mathrm{AD}$.

Drug addiction. Drug addiction is recognized as a type of neuroadaptive disorder. Because the ERK1/2 pathway plays an important role in neuronal plasticity in the adult brain, understanding of the role of this pathway is critical for overall understanding of the molecular mechanisms underlying drug addiction and relapse. Exposure to a variety of substances with abuse potential, including nicotine, alcohol, amphetamine and cocaine, acutely active ERK1/2 in the striatum and other brain areas (94-97). Many of the enduring behavioral effects of acute drug exposure depend on ERK1/2 signaling. Studies have suggested that ERK1/2 is dynamically regulated following repeated drug exposure and withdrawal and that changes in ERK1/2 activation directly affect striatal cell excitability $(98,99)$. These effects may be responsible for the expression of addictive behavior, and alterations of this pathway may contribute to the drug's rewarding effects and to the long-term maladaptation induced by drug abuse. Evidence indicates that ERK1/2 plays a dual role in gene regulation and drug addiction through direct activation of transcription factors, including Elk1 and cAMP response element-binding protein (CREB), and by chromatin remodeling via MSK1 and histone H3 phosphorylation $(100,101)$. Because ERK1/2 activation is a key molecular process in drug self-administration, targeting it may be a potential treatment strategy for drug addiction.

Other neurological diseases. Amyotrophic lateral sclerosis (ALS) is a CNS disease that causes the death of motor neurons and that can be either sporadic or familial origin. Mutant SOD1 is one of the genetic factors that contribute to the etiology of ALS, and mutant SOD1 induces motor neuron vulnerability. Phosphorylated ERK1/2 has been shown to be increased in the hippocampus and cerebellum in SOD1 G93A transgenic models (102). Apolloni et al (103) showed that ERK1/2 also participates in P2X7 receptor-induced enhancement of oxidative stress in ALS microglia, together with the NOX2 pathway. A previous study also identified ERK1/2 as a novel player in the pathogenesis of ALS associated with transactive response DNA-binding protein 43 (TDP-43) (77). A recent study also showed that depletion of TDP-43 in microglia strikingly upregulated the production of COX-2 and PGE2 through the activation of ERK1/2 signaling (61).

Huntington's disease (HD), a devastating neurodegenerative disease that is characterized by progressive and severe cognitive, psychiatric and motor dysfunction, is caused by an expanded CAG repeat in the huntingtin ( $\mathrm{Htt})$ gene. MAPK signaling, and particularly the Ras-ERK cascade, is among the pathways that have been implicated in HD. In response to mutant huntingtin, ERK1/2 is activated and directs a protective transcriptional response and inhibits apoptotic caspase-3 and -7 activation $(104,105)$. Data from different model systems indicate that ERK1/2 is involved in HD excitotoxicity at both the intercellular and intracellular level (106-108). Pharmacological interventions that promote ERK1/2 activation could suppress the adverse effects of mutant Htt by activating pro-survival mechanisms and suppressing apoptotic responses. Thus, studies in both cells and animal models suggest that the ERK1/2 cascade may be a potential target for therapeutic interventions for currently untreatable disorders.

\section{Therapeutic inhibitors of the ERK1/2 signaling cascade}

ERK1/2 pathway regulated kinase is a central point in the signaling network and is firmly established as an attractive target for pharmacological intervention in many diseases. Currently, inhibitors of the kinase function of Raf and MEK represent the most studied and advanced approaches for blocking the ERK1/2 pathway, with several inhibitors under evaluation in clinical trials and additional inhibitors in preclinical analyses. Morever, many neurological disease-related studies have investigated the effects of ERK1/2 pathway inhibitors, whose main mechanism of action is to prevent the phosphorylation of ERK1 and 2 by the upstream kinases, MEK1 and 2. A number of highly selective MEK1/2 inhibitors have been development, and many of them have been tested in a clinical setting. PD98059 and U0126 are first-generation small-molecule inhibitors of MEK1/2. In preclinical study, they feature potency and high specificity, with no or little inhibitory effects on other kinase. Most Raf inhibitors target mutant B-Raf and the most extensively studied B-Raf inhibitor in neurological disease is SB386023-b. Both Raf and MEK inhibitors have been widely applied in many experimental studies to better understand this pathway and explore its roles in neurological diseases (Table I). Other selected new and emerging MEK inhibitors have not been well studied in neurological diseases, such as PD0325901, selumetinib, cobimetinib, refametinib and trametinib. The main results obtained to date strongly suggest that the ERK1/2 pathway may represent a valid therapeutic target in neurological disorder conditions. Finally, it has also been proposed that ERK1/2 pathway may be a significant tool through which to study stroke, neurodegenerative disease and drug addiction.

\section{Summary and perspectives}

In summary, the link between the ERK1/2 signaling pathway and a variety of neurological diseases, including stroke, neurodegenerative diseases and drug addiction, demonstrates the importance of studying the ERK1/2 pathway to human health. More detailed knowledge of the physiological and pathological functions of ERK1/2 in the adult nervous system may not only provide insight for the development of new therapeutic drugs for neurological disorders but also achieve clinical benefits for patients. Over the next several years, additional novel therapeutic strategies that utilize ERK1/2 signaling inhibitors will likely be developed for neurological disease clinical trials. 


\section{References}

1. Zhu X, Castellani RJ, Takeda A, Nunomura A, Atwood CS Perry G and Smith MA: Differential activation of neuronal ERK, JNK/SAPK and p38 in Alzheimer disease: the 'two hit' hypothesis Mech Ageing Dev 123: 39-46, 2001.

2. Roberts PJ and Der CJ: Targeting the Raf-MEK-ERK mitogen-activated protein kinase cascade for the treatment of cancer. Oncogene 26: 3291-3310, 2007.

3. Shioda N, Han F and Fukunaga K: Role of Akt and ERK signaling in the neurogenesis following brain ischemia. Int Rev Neurobiol 85: 375-387, 2009 .

4. Alam R and Gorska MM: Mitogen-activated protein kinase signalling and ERK1/2 bistability in asthma. Clin Exp Allergy 41: 149-159, 2011.

5. Yao Y, Li W, Wu J, Germann UA, Su MS, Kuida K and Boucher DM: Extracellular signal-regulated kinase 2 is necessary for mesoderm differentiation. Proc Natl Acad Sci USA 100: 12759-12764, 2003.

6. Pagès G, Guérin S, Grall D, Bonino F, Smith A, Anjuere F, Auberger P and Pouysségur J: Defective thymocyte maturation in p44 MAP kinase (Erk 1) knockout mice. Science 286: 1374-1377, 1999

7. Charest DL, Mordret G, Harder KW, Jirik F and Pelech SL: Molecular cloning, expression, and characterization of the human mitogen-activated protein kinase p44erk1. Mol Cell Biol 13: 4679-4690, 1993

8. Lefloch R, Pouysségur J and Lenormand P: Total ERK1/2 activity regulates cell proliferation. Cell Cycle 8: 705-711, 2009.

9. Lefloch R, Pouysségur J and Lenormand P: Single and combined silencing of ERK1 and ERK2 reveals their positive contribution to growth signaling depending on their expression levels. Mol Cell Biol 28: 511-527, 2008

10. Raman M, Chen W and Cobb MH: Differential regulation and properties of MAPKs. Oncogene 26: 3100-3112, 2007.

11. Ji RR, Gereau RW IV, Malcangio M and Strichartz GR: MAP kinase and pain. Brain Res Brain Res Rev 60: 135-148, 2009.

12. Lorenz K, Schmitt JP, Vidal M and Lohse MJ: Cardiac hypertrophy: targeting Raf/MEK/ERK1/2-signaling. Int J Biochem Cell Biol 41: 2351-2355, 2009.

13. Cui Y, Wu J, Jung SC, Park DB, Maeng YH, Hong JY, Kim SJ, Lee SR, Kim SJ, Kim SJ, et al: Anti-neuroinflammatory activity of nobiletin on suppression of microglial activation. Biol Pharm Bull 33: 1814-1821, 2010.

14. Zhu C, Qi X, Chen Y, Sun B, Dai Y and Gu Y: PI3K/Akt and MAPK/ERK1/2 signaling pathways are involved in IGF-1-induced VEGF-C upregulation in breast cancer. J Cancer Res Clin Oncol 137: 1587-1594, 2011

15. Yoon S and Seger R: The extracellular signal-regulated kinase: multiple substrates regulate diverse cellular functions. Growth Factors 24: 21-44, 2006.

16. Murphy LO and Blenis J: MAPK signal specificity: the right place at the right time. Trends Biochem Sci 31: 268-275, 2006.

17. Dhillon AS, Hagan S, Rath O and Kolch W: MAP kinase signalling pathways in cancer. Oncogene 26: 3279-3290, 2007.

18. Anjum R and Blenis J: The RSK family of kinases: emerging roles in cellular signalling. Nat Rev Mol Cell Biol 9: 747-758, 2008.

19. Yao Z and Seger R: The ERK signaling cascade - views from different subcellular compartments. Biofactors 35: 407-416, 2009.

20. Lavoie $H$ and Therrien M: Regulation of RAF protein kinases in ERK signalling. Nat Rev Mol Cell Biol 16: 281-298, 2015.

21. Schaeffer HJ, Catling AD, Eblen ST, Collier LS, Krauss A and Weber MJ: MP1: a MEK binding partner that enhances enzymatic activation of the MAP kinase cascade. Science 281: 1668-1671, 1998

22. Brahma A and Dalby KN: Regulation of protein phosphorylation within the MKK1-ERK2 complex by MP1 and the MP1・P14 heterodimer. Arch Biochem Biophys 460: 85-91, 2007.

23. Jameson KL, Mazur PK, Zehnder AM, Zhang J, Zarnegar B, Sage J and Khavari PA: IQGAP1 scaffold-kinase interaction blockade selectively targets RAS-MAP kinase-driven tumors. Nat Med 19: 626-630, 2013.

24. Xu S, Robbins D, Frost J, Dang A, Lange-Carter C and Cobb MH: MEKK1 phosphorylates MEK1 and MEK2 but does not cause activation of mitogen-activated protein kinase. Proc Natl Acad Sci USA 92: 6808-6812, 1995.

25. Karandikar M, Xu S and Cobb MH: MEKK1 binds raf-1 and the ERK2 cascade components. J Biol Chem 275: 40120-40127, 2000 .
26. Brennan DF, Dar AC, Hertz NT, Chao WC, Burlingame AL, Shokat KM and Barford D: A Raf-induced allosteric transition of KSR stimulates phosphorylation of MEK. Nature 472: 366-369, 2011

27. Hu J, Yu H, Kornev AP, Zhao J, Filbert EL, Taylor SS and Shaw AS: Mutation that blocks ATP binding creates a pseudokinase stabilizing the scaffolding function of kinase suppressor of Ras, CRAF and BRAF. Proc Natl Acad Sci USA 108: 6067-6072, 2011.

28. Kim EK and Choi EJ: Pathological roles of MAPK signaling pathways in human diseases. Biochim Biophys Acta 1802: 396-405, 2010.

29. Impey S, Obrietan K and Storm DR: Making new connections: role of ERK/MAP kinase signaling in neuronal plasticity. Neuron 23: 11-14, 1999.

30. Di Cristo G, Berardi N, Cancedda L, Pizzorusso T, Putignano E, Ratto GM and Maffei L: Requirement of ERK activation for visual cortical plasticity. Science 292: 2337-2340, 2001.

31. English JD and Sweatt JD: A requirement for the mitogen-activated protein kinase cascade in hippocampal long term potentiation. J Biol Chem 272: 19103-19106, 1997.

32. Kanterewicz BI, Urban NN, McMahon DB, Norman ED Giffen LJ, Favata MF, Scherle PA, Trzskos JM, Barrionuevo G and Klann E: The extracellular signal-regulated kinase cascade is require for NMDA receptor-independent LTP in area CA1 but not area CA3 of the hippocampus. J Neurosci 20: 3057-3066, 2000.

33. Huang SS, He J, Zhao DM, Xu XY, Tan HP and Li H: Effects of mutant huntingtin on mGluR5-mediated dual signaling pathways: implications for therapeutic interventions. Cell Mol Neurobiol 30: 1107-1115, 2010.

34. Schafe GE, Atkins CM, Swank MW, Bauer EP, Sweatt JD and LeDoux JE: Activation of ERK/MAP kinase in the amygdala is required for memory consolidation of pavlovian fear conditioning. J Neurosci 20: 8177-8187, 2000.

35. Ratto GM and Pizzorusso T: A kinase with a vision: role of ERK in the synaptic plasticity of the visual cortex. Adv Exp Med Biol 557: 122-132, 2006.

36. Thiels E, Kanterewicz BI, Norman ED, Trzaskos JM and Klann E: Long-term depression in the adult hippocampus in vivo involves activation of extracellular signal-regulated kinase and phosphorylation of Elk-1. J Neurosci 22: 2054-2062, 2002.

37. Imamura $\mathrm{O}$, Pagès $\mathrm{G}$, Pouysségur $\mathrm{J}$, Endo $\mathrm{S}$ and Takishima $\mathrm{K}$ : ERK1 and ERK2 are required for radial glial maintenance and cortical lamination. Genes Cells 15: 1072-1088, 2010.

38. Fyffe-Maricich SL, Karlo JC, Landreth GE and Miller RH: The ERK2 mitogen-activated protein kinase regulates the timing of oligodendrocyte differentiation. J Neurosci 31: 843-850, 2011.

39. Samuels IS, Karlo JC, Faruzzi AN, Pickering K, Herrup K, Sweatt JD, Saitta SC and Landreth GE: Deletion of ERK2 mitogen-activated protein kinase identifies its key roles in cortical neurogenesis and cognitive function. J Neurosci 28: 6983-6995, 2008.

40. Samuels IS, Saitta SC and Landreth GE: MAP'ing CNS development and cognition: an ERKsome process. Neuron 61: 160-167, 2009.

41. Li X, Newbern JM, Wu Y, Morgan-Smith M, Zhong J, Charron J and Snider WD: MEK is a key regulator of gliogenesis in the developing brain. Neuron 75: 1035-1050, 2012.

42. Domercq M, Alberdi E, Sánchez-Gómez MV, Ariz U, Pérez-Samartín A and Matute C: Dual-specific phosphatase-6 (Dusp6) and ERK mediate AMPA receptor-induced oligodendrocyte death. J Biol Chem 286: 11825-11836, 2011.

43. Newbern JM, Li X, Shoemaker SE, Zhou J, Zhong J, Wu Y, Bonder D, Hollenback S, Coppola G, Geschwind DH, et al: Specific functions for ERK/MAPK signaling during PNS development. Neuron 69: 91-105, 2011.

44. Fyffe-Maricich SL, Schott A, Karl M, Krasno J and Miller RH: Signaling through ERK1/2 controls myelin thickness during myelin repair in the adult central nervous system. J Neurosci 33 : 18402-18408, 2013.

45. Satoh T, Nakatsuka D, Watanabe Y, Nagata I, Kikuchi H and Namura S: Neuroprotection by MAPK/ERK kinase inhibition with U0126 against oxidative stress in a mouse neuronal cell line and rat primary cultured cortical neurons. Neurosci Lett 288: 163-166, 2000.

46. Subramaniam $\mathrm{S}$ and Unsicker K: ERK and cell death: ERK1/2 in neuronal death. FEBS J 277: 22-29, 2010.

47. Jiang Q, Gu Z, Zhang G and Jing G: Diphosphorylation and involvement of extracellular signal-regulated kinases (ERK1/2) in glutamate-induced apoptotic-like death in cultured rat cortical neurons. Brain Res 857: 71-77, 2000. 
48. Benvenisti-Zarom L, Chen-Roetling J and Regan RF: Inhibition of the ERK/MAP kinase pathway attenuates heme oxygenase-1 expression and heme-mediated neuronal injury. Neurosci Lett 398: 230-234, 2006.

49. Namura S, Iihara K, Takami S, Nagata I, Kikuchi H, Matsushita K, Moskowitz MA, Bonventre JV and Alessandrini A: Intravenous administration of MEK inhibitor U0126 affords brain protection against forebrain ischemia and focal cerebral ischemia. Proc Natl Acad Sci USA 98: 11569-11574, 2001

50. Zhao Y, Luo P, Guo Q, Li S, Zhang L, Zhao M, Xu H, Yang Y, Poon W and Fei Z: Interactions between SIRT1 and MAPK/ERK regulate neuronal apoptosis induced by traumatic brain injury in vitro and in vivo. Exp Neurol 237: 489-498, 2012.

51. Rundén E, Seglen PO, Haug FM, Ottersen OP, Wieloch T, Shamloo M and Laake JH: Regional selective neuronal degeneration after protein phosphatase inhibition in hippocampal slice cultures: evidence for a MAP kinase-dependent mechanism. J Neurosci 18: 7296-7305, 1998.

52. Perry VH and Teeling J: Microglia and macrophages of the central nervous system: the contribution of microglia priming and systemic inflammation to chronic neurodegeneration. Semin Immunopathol 35: 601-612, 2013.

53. Weinstein JR, Zhang M, Kutlubaev M, Lee R, Bishop C, Andersen H, Hanisch UK and Möller T: Thrombin-induced regulation of CD95(Fas) expression in the N9 microglial cell line: evidence for involvement of proteinase-activated receptor(1) and extracellular signal-regulated kinase $1 / 2$. Neurochem Res 34: 445-452, 2009.

54. Deng Z, Sui G, Rosa PM and Zhao W: Radiation-induced c-Jun activation depends on MEK1-ERK1/2 signaling pathway in microglial cells. PLoS One 7: e36739, 2012.

55. Kim S, Lee MS, Lee B, Gwon WG, Joung EJ, Yoon NY and Kim HR: Anti-inflammatory effects of sargachromenol-rich ethanolic extract of Myagropsis myagroides on lipopolysaccharide-stimulated BV-2 cells. BMC Complement Altern Med 14: 231, 2014

56. Park GH, Jeon SJ, Ryu JR, Choi MS, Han SH, Yang SI, Ryu JH, Cheong JH, Shin CY and Ko KH: Essential role of mitogen-activated protein kinase pathways in protease activated receptor 2-mediated nitric-oxide production from rat primary astrocytes. Nitric Oxide 21: 110-119, 2009.

57. Fields J, Cisneros IE, Borgmann K and Ghorpade A: Extracellular regulated kinase $1 / 2$ signaling is a critical regulator of interleukin-1 $\beta$-mediated astrocyte tissue inhibitor of metalloproteinase-1 expression. PLoS One 8: e56891, 2013.

58. Wang YJ, Zheng YL, Lu J, Chen GQ, Wang XH, Feng J, Ruan J, Sun X, Li CX and Sun QJ: Purple sweet potato color suppresses lipopolysaccharide-induced acute inflammatory response in mouse brain. Neurochem Int 56: 424-430, 2010.

59. Shao J, Liu T, Xie QR, Zhang T, Yu H, Wang B, Ying W, Mruk DD, Silvestrini B, Cheng CY, et al: Adjudin attenuates lipopolysaccharide (LPS)- and ischemia-induced microglial activation. J Neuroimmunol 254: 83-90, 2013.

60. Zhao H, Wang SL, Qian L, Jin JL, Li H, Xu Y and Zhu XL: Diammonium glycyrrhizinate attenuates $A \beta(1-42)$-induced neuroinflammation and regulates MAPK and NF- $\kappa$ B pathways in vitro and in vivo. CNS Neurosci Ther 19: 117-124, 2013.

61. Xia Q, Hu Q, Wang H, Yang H, Gao F, Ren H, Chen D, Fu C, Zheng L, Zhen X, et al: Induction of COX-2-PGE2 synthesis by activation of the MAPK/ERK pathway contributes to neuronal death triggered by TDP-43-depleted microglia. Cell Death Dis 6: e1702, 2015.

62. Fiore RS, Bayer VE, Pelech SL, Posada J, Cooper JA and Baraban JM: p42 mitogen-activated protein kinase in brain prominent localization in neuronal cell bodies and dendrites. Neuroscience 55: 463-472, 1993.

63. Atkins CM, Selcher JC, Petraitis JJ, Trzaskos JM and Sweatt JD: The MAPK cascade is required for mammalian associative learning. Nat Neurosci 1: 602-609, 1998.

64. Feld M, Dimant B, Delorenzi A, Coso O and Romano A: Phosphorylation of extra-nuclear ERK/MAPK is required for long-term memory consolidation in the crab Chasmagnathus. Behav Brain Res 158: 251-261, 2005.

65. Igaz LM, Winograd M, Cammarota M, Izquierdo LA, Alonso M, Izquierdo I and Medina JH: Early activation of extracellular signal-regulated kinase signaling pathway in the hippocampus is required for short-term memory formation of a fear-motivated learning. Cell Mol Neurobiol 26: 989-1002, 2006.
66. Kelly A, Laroche S and Davis S: Activation of mitogen-activated protein kinase/extracellular signal-regulated kinase in hippocampal circuitry is required for consolidation and reconsolidation of recognition memory. J Neurosci 23: 5354-5360, 2003.

67. Villarreal JS and Barea-Rodriguez EJ: ERK phosphorylation is required for retention of trace fear memory. Neurobiol Learn Mem 85: 44-57, 2006.

68. Shalin SC, Zirrgiebel U, Honsa KJ, Julien JP, Miller FD, Kaplan DR and Sweatt JD: Neuronal MEK is important for normal fear conditioning in mice. J Neurosci Res 75: 760-770, 2004.

69. Satoh Y, Endo S, Ikeda T, Yamada K, Ito M, Kuroki M, Hiramoto T, Imamura O, Kobayashi Y, Watanabe Y, et al: Extracellular signal-regulated kinase 2 (ERK2) knockdown mice show deficits in long-term memory; ERK2 has a specific function in learning and memory. J Neurosci 27: 10765-10776, 2007.

70. Selcher JC, Nekrasova T, Paylor R, Landreth GE and Sweatt JD: Mice lacking the ERK1 isoform of MAP kinase are unimpaired in emotional learning. Learn Mem 8: 11-19, 2001.

71. Saba-El-Leil MK, Vella FD, Vernay B, Voisin L, Chen L, Labrecque N, Ang SL and Meloche S: An essential function of the mitogen-activated protein kinase Erk2 in mouse trophoblast development. EMBO Rep 4: 964-968, 2003.

72. Mazzucchelli C, Vantaggiato C, Ciamei A, Fasano S, Pakhotin P, Krezel W, Welzl H, Wolfer DP, Pagès G, Valverde $\mathrm{O}$, et al: Knockout of ERK1 MAP kinase enhances synaptic plasticity in the striatum and facilitates striatal-mediated learning and memory. Neuron 34: 807-820, 2002.

73. Cestari V, Costanzi M, Castellano C and Rossi-Arnaud C: A role for ERK2 in reconsolidation of fear memories in mice. Neurobiol Learn Mem 86: 133-143, 2006.

74. Ferrer I, Blanco R, Carmona M, Ribera R, Goutan E, Puig B, Rey MJ, Cardozo A, Viñals F and Ribalta T: Phosphorylated map kinase (ERK1, ERK2) expression is associated with early tau deposition in neurones and glial cells, but not with increased nuclear DNA vulnerability and cell death, in Alzheimer disease, Pick's disease, progressive supranuclear palsy and corticobasal degeneration. Brain Pathol 11: 144-158, 2001.

75. Santini E, Valjent E, Usiello A, Carta M, Borgkvist A, Girault JA, Hervé D, Greengard P and Fisone G: Critical involvement of cAMP/DARPP-32 and extracellular signal-regulated protein kinase signaling in L-DOPA-induced dyskinesia. J Neurosci 27: 6995-7005, 2007.

76. Ahnstedt H, Säveland H, Nilsson O and Edvinsson L: Human cerebrovascular contractile receptors are upregulated via a B-Raf/MEK/ERK-sensitive signaling pathway. BMC Neurosci 12: 5, 2011

77. Ayala V, Granado-Serrano AB, Cacabelos D, Naudí A, Ilieva EV, Boada J, Caraballo-Miralles V, Lladó J, Ferrer I, Pamplona R, et al: Cell stress induces TDP-43 pathological changes associated with ERK1/2 dysfunction: implications in ALS. Acta Neuropathol 122: 259-270, 2011.

78. Feld M, Krawczyk MC, Sol Fustiñana M, Blake MG, Baratti CM, Romano A and Boccia MM: Decrease of ERK/MAPK overactivation in prefrontal cortex reverses early memory deficit in a mouse model of Alzheimer's disease. J Alzheimers Dis 40: 69-82, 2014.

79. Fujimoto S, Katsuki H, Ohnishi M, Takagi M, Kume T and Akaike A: Thrombin induces striatal neurotoxicity depending on mitogen-activated protein kinase pathways in vivo. Neuroscience 144: 694-701, 2007.

80. Maddahi A, Ansar S, Chen Q and Edvinsson L: Blockade of the MEK/ERK pathway with a raf inhibitor prevents activation of pro-inflammatory mediators in cerebral arteries and reduction in cerebral blood flow after subarachnoid hemorrhage in a rat model. J Cereb Blood Flow Metab 31: 144-154, 2011

81. Ohnishi M, Katsuki H, Fujimoto S, Takagi M, Kume T and Akaike A: Involvement of thrombin and mitogen-activated protein kinase pathways in hemorrhagic brain injury. Exp Neurol 206: 43-52, 2007.

82. Maddahi A and Edvinsson L: Cerebral ischemia induces microvascular pro-inflammatory cytokine expression via the MEK/ERK pathway. J Neuroinflammation 7: 14, 2010.

83. Maddahi A, Povlsen GK and Edvinsson L: Regulation of enhanced cerebrovascular expression of proinflammatory mediators in experimental subarachnoid hemorrhage via the mitogen-activated protein kinase kinase/extracellular signal-regulated kinase pathway. J Neuroinflammation 9: 274,2012 . 
84. Ansar S, Maddahi A and Edvinsson L: Inhibition of cerebrovascular raf activation attenuates cerebral blood flow and prevents upregulation of contractile receptors after subarachnoid hemorrhage. BMC Neurosci 12: 107, 2011.

85. Feng D, Wang B, Ma Y, Shi W, Tao K, Zeng W, Cai Q, Zhang Z and Qin H: The Ras/Raf/Erk pathway mediates the subarachnoid hemorrhage-induced apoptosis of hippocampal neurons through phosphorylation of p53. Mol Neurobiol 53: 5737-5748 2016.

86. Liu Y, Qin L, Li G, Zhang W, An L, Liu B and Hong JS Dextromethorphan protects dopaminergic neurons against inflammation-mediated degeneration through inhibition of microglial activation. J Pharmacol Exp Ther 305: 212-218, 2003

87. Qian L, Tan KS, Wei SJ, Wu HM, Xu Z, Wilson B, Lu RB, Hong JS and Flood PM: Microglia-mediated neurotoxicity is inhibited by morphine through an opioid receptor-independent reduction of NADPH oxidase activity. J Immunol 179 : 1198-1209, 2007.

88. ValjentE, Pascoli V, Svenningsson P, Paul S, Enslen H, Corvol JC, Stipanovich A, Caboche J, Lombroso PJ, Nairn AC, et al Regulation of a protein phosphatase cascade allows convergent dopamine and glutamate signals to activate ERK in the striatum. Proc Natl Acad Sci USA 102: 491-496, 2005.

89. Santini E, Sgambato-Faure V, Li Q, Savasta M, Dovero S Fisone $G$ and Bezard E: Distinct changes in cAMP and extracellular signal-regulated protein kinase signalling in L-DOPA-induced dyskinesia. PLoS One 5: e12322, 2010.

90.Lindgren HS, Ohlin KE and Cenci MA: Differential involvement of D1 and D2 dopamine receptors in L-DOPA-induced angiogenic activity in a rat model of Parkinson's disease. Neuropsychopharmacology 34: 2477-2488, 2009.

91.Pei JJ, Braak H, An WL, Winblad B, Cowburn RF, Iqbal K and Grundke-Iqbal I: Up-regulation of mitogen-activated protein kinases ERK1/2 and MEK1/2 is associated with the progression of neurofibrillary degeneration in Alzheimer's disease. Brain Res Mol Brain Res 109: 45-55, 2002.

92.Zhu X, Lee HG, Raina AK, Perry G and Smith MA: The role of mitogen-activated protein kinase pathways in Alzheimer's disease. Neurosignals 11: 270-281, 2002.

93.Liu F, Su Y, Li B and Ni B: Regulation of amyloid precursor protein expression and secretion via activation of ERK1/2 by hepatocyte growth factor in HEK293 cells transfected with APP751. Exp Cell Res 287: 387-396, 2003.

94.Lu L, Koya E, Zhai H, Hope BT and Shaham Y: Role of ERK in cocaine addiction. Trends Neurosci 29: 695-703, 2006.

95. Hoffmann HM, Nadal R, Vignes M and Ortiz J: Chronic cocaine self-administration modulates ERK1/2 and CREB responses to dopamine receptor agonists in striatal slices. Addict Biol 17: 565-575, 2012.

96.Pascoli V, Cahill E, Bellivier F, Caboche J and Vanhoutte P: Extracellular signal-regulated protein kinases 1 and 2 activation by addictive drugs: a signal toward pathological adaptation. Biol Psychiatry 76: 917-926, 2014.

97. Agoglia AE, Sharko AC, Psilos KE, Holstein SE, Reid GT and Hodge CW: Alcohol alters the activation of ERK1/2, a functional regulator of binge alcohol drinking in adult $\mathrm{C} 57 \mathrm{BL} / 6 \mathrm{~J}$ mice. Alcohol Clin Exp Res 39: 463-475, 2015.

98. Boudreau AC, Reimers JM, Milovanovic M and Wolf ME: Cell surface AMPA receptors in the rat nucleus accumbens increase during cocaine withdrawal but internalize after cocaine challenge in association with altered activation of mitogen-activated protein kinases. J Neurosci 27: 10621-10635, 2007.

99. Schumann J and Yaka R: Prolonged withdrawal from repeated noncontingent cocaine exposure increases NMDA receptor expression and ERK activity in the nucleus accumbens. J Neurosci 29: 6955-6963, 2009.

100. Brami-Cherrier K, Roze E, Girault JA, Betuing S and Caboche J: Role of the ERK/MSK1 signalling pathway in chromatin remodelling and brain responses to drugs of abuse. J Neurochem 108 $1323-1335,2009$.

101. Ciccarelli A and Giustetto M: Role of ERK signaling in activity-dependent modifications of histone proteins. Neuropharmacology 80: 34-44, 2014.

102. Chung YH, Joo KM, Lim HC, Cho MH, Kim D, Lee WB and Cha CI: Immunohistochemical study on the distribution of phosphorylated extracellular signal-regulated kinase (ERK) in the central nervous system of SOD $1^{\mathrm{G} 93 \mathrm{~A}}$ transgenic mice. Brain Res 1050: 203-209, 2005.
103. Apolloni S, Parisi C, Pesaresi MG, Rossi S, Carrì MT, Cozzolino M, Volonté C and D'Ambrosi N: The NADPH oxidase pathway is dysregulated by the $\mathrm{P} 2 \mathrm{X}_{7}$ receptor in the SOD1-G93A microglia model of amyotrophic lateral sclerosis. J Immunol 190: 5187-5195, 2013.

104. Apostol BL, Illes K, Pallos J, Bodai L, Wu J, Strand A, Schweitzer ES, Olson JM, Kazantsev A, Marsh JL, et al: Mutant huntingtin alters MAPK signaling pathways in PC12 and striatal cells: ERK1/2 protects against mutant huntingtin-associated toxicity. Hum Mol Genet 15: 273-285, 2006.

105. Varma H, Cheng R, Voisine C, Hart AC and Stockwell BR: Inhibitors of metabolism rescue cell death in Huntington's disease models. Proc Natl Acad Sci USA 104: 14525-14530, 2007.

106. Liévens JC, Rival T, Iché M, Chneiweiss H and Birman S: Expanded polyglutamine peptides disrupt EGF receptor signaling and glutamate transporter expression in Drosophila. Hum Mol Genet 14: 713-724, 2005.

107. Huang YY, Martin KC and Kandel ER: Both protein kinase A and mitogen-activated protein kinase are required in the amygdala for the macromolecular synthesis-dependent late phase of long-term potentiation. J Neurosci 20: 6317-6325, 2000.

108. Ribeiro FM, Paquet M, Ferreira LT, Cregan T, Swan P, Cregan SP and Ferguson SS: Metabotropic glutamate receptor-mediated cell signaling pathways are altered in a mouse model of Huntington's disease. J Neurosci 30: 316-324, 2010.

109. Maddahi A, Chen Q and Edvinsson L: Enhanced cerebrovascular expression of matrix metalloproteinase- 9 and tissue inhibitor of metalloproteinase-1 via the MEK/ERK pathway during cerebral ischemia in the rat. BMC Neurosci 10: 56, 2009.

110. Ahnstedt H, Mostajeran M, Blixt FW, Warfvinge K, Ansar S, Krause DN and Edvinsson L: U0126 attenuates cerebral vasoconstriction and improves long-term neurologic outcome after stroke in female rats. J Cereb Blood Flow Metab 35: 454-460, 2015.

111. Vikman P, Ansar S, Henriksson M, Stenman E and Edvinsson L: Cerebral ischemia induces transcription of inflammatory and extracellular-matrix-related genes in rat cerebral arteries. Exp Brain Res 183: 499-510, 2007.

112. Maddahi A, Kruse LS, Chen QW and Edvinsson L: The role of tumor necrosis factor- $\alpha$ and TNF- $\alpha$ receptors in cerebral arteries following cerebral ischemia in rat. J Neuroinflammation 8: $107,2011$.

113. Zhang J, Xu X, Zhou D, Li H, You W, Wang Z and Chen G: Possible role of Raf-1 kinase in the development of cerebral vasospasm and early brain injury after experimental subarachnoid hemorrhage in rats. Mol Neurobiol 52: 1527-1539, 2015.

114. Beg SA, Hansen-Schwartz JA, Vikman PJ, Xu CB and Edvinsson LI: ERK1/2 inhibition attenuates cerebral blood flow reduction and abolishes ET(B) and 5-HT(1B) receptor upregulation after subarachnoid hemorrhage in rat. J Cereb Blood Flow Metab 26: 846-856, 2006.

115. Li J, Fan Y, Zhang YN, Sun DJ, Fu SB, Ma L, Jiang LH, Cui C, Ding HF and Yang J: The Raf-1 inhibitor GW5074 and the ERK1/2 pathway inhibitor U0126 ameliorate PC12 cells apoptosis induced by 6-hydroxydopamine. Pharmazie 67: 718-724, 2012.

116. Bartolomé F, de Las Cuevas N, Muñoz U, Bermejo F and Martín-Requero A: Impaired apoptosis in lymphoblasts from Alzheimer's disease patients: cross-talk of $\mathrm{Ca}^{2+} / \mathrm{calmodulin}$ and ERK1/2 signaling pathways. Cell Mol Life Sci 64: 1437-1448, 2007.

117. Pei JJ, Gong CX, An WL, Winblad B, Cowburn RF, GrundkeIqbal I and Iqbal K: Okadaic-acid-induced inhibition of protein phosphatase $2 \mathrm{~A}$ produces activation of mitogen-activated protein kinases ERK1/2, MEK1/2, and p70 S6, similar to that in Alzheimer's disease. Am J Pathol 163: 845-858, 2003.

118. Chong YH, Shin YJ, Lee EO, Kayed R, Glabe CG and Tenner AJ: ERK1/2 activation mediates Abeta oligomer-induced neurotoxicity via caspase- 3 activation and tau cleavage in rat organotypic hippocampal slice cultures. J Biol Chem 281: 20315-20325, 2006

119. Andersen JM, Myhre O and Fonnum F: Discussion of the role of the extracellular signal-regulated kinase-phospholipase A2 pathway in production of reactive oxygen species in Alzheimer's disease. Neurochem Res 28: 319-326, 2003.

120. Pan B,Zhong P, Sun D and Liu QS: Extracellular signal-regulated kinase signaling in the ventral tegmental area mediates cocaine-induced synaptic plasticity and rewarding effects. J Neurosci 31: 11244-11255, 2011. 